\title{
The Existence of Makka Keke's Belief System in Gantarang, Selayar
}

\author{
Hasaruddin \\ hasaruddinsyarif@yahoo.com \\ The State Islamic University of Alauddin Makassar \\ Misbahuddin \\ ibnul.arman@gmail.com \\ The State Islamic University of Alauddin Makassar
}

\begin{abstract}
The impurity of Islam understood by most Indonesian Muslims at the beginning of dissemination constitutes to a form of adaptation through assimilation between Islam and local tradition that animism and dynamism are found, so that the Indonesian Muslims show things that are contrary with principles of Islam, especially those are related to the principles of Islamic's theology that rejects all forms of musyrik and khurafat. The sinkretisme happens and experiences over all archipelago in general and continues to be-so, at least before some Islamic reform movement is present as neutralizing the situation. The existences of Islamic reform movements are not able to eliminate the ongoing process of acculturation. There is no much efforts provided considering that all movements in colonial period are limited. It is only at the time of Indonesia's independence that is all movements by reformist and traditional ulama are in move to act the upheaval including those take place in Selayar with Makka Keke's belief system in the village of Gantarang.
\end{abstract}

Keywords: Islam in Selayar, The Belief System of Makka Keke, Existence and Its Impact to Society.

\section{Introduction}

The faith can be explained in terms of the process of worship performed by a person or people to the power and the 
will outside him. In the conduct of life, humans experience, either consciously or not, events that are not always able to control it, even for unwanted things. At that time, it is realized that there is a force outside of them that cannot be conquered. The next step taken to look forward to guessing the source of such power. The source of supernatural power usually refers to the macrocosm of nature that is found around, such as large trees, large rocks, gods and goddesses. This belief is nothing, but the expression of a sense of unseen things that people experience over the world (numinous).

Rudolf Otto, a religious historian wrote that the sense of the unseen things (numinous) is the basis of religion. That feeling that precedes any desire to explain the origin of the world or find a basis for ethical behavior. The strength of unseen things perceived by humans in different circumstances, sometimes inspired by the wild and intoxicating joy, tranquility deep, wry, awe, and despicable before the presence of the mysterious force that is inherent in every aspect of life. ${ }^{1}$

Every human being has the religion feeling that he has bringing with himself/herself as diviniatus census. The feeling whether grows up or not or dies or not, basically depends on individual's environment. Religions and belief systems of society are one of the elements of human culture as a whole. Other systems include of systems and social organization, system of knowledge, language, arts, subsistence, technology, and equipment. ${ }^{2}$

Koentjaraningrat established of the essential elements that existed in a religion, namely: (1) religious emotion, (2) a

\footnotetext{
${ }^{1}$ Karen Armstrong, A History of God: The 4,000-Year Quest of Judaism, Christianity and Islam, terj. Zaimul Am, Sejarah Tuhan: Kisah 4.000

Tahun Pencarian Tuhan dalam Agama-Agama Manusia (Cet. V;

Bandung: Mizan Pustaka, 2012), h. 29-30.

${ }^{2}$ Koentjaraningrat, Kebudayaan, Mentalitas dan Pembangunan (Cet. XXI; Jakarta: PT. Gramedia Pustaka Utama, 2015), h. 2.
} 
belief system, (3) a system of religious ceremonies, and (4) a community that embraces it. $^{3}$ A religious system in a culture always has characteristics to maintain as possible the religious emotions among followers that will automatically keep the purity of the teachings continued existence as well as possible. In such condition, a characteristic is found in religion will always be maintained originality, without any assimilation between the purity of the foreign matters coming from outside.

The uncompletion of the teachings of Islam which is brought to the various parts of the archipelago with the very soft and compromise with local tradition which has long been rooted becomes one of the triggers easily shift and acculturation value in terms of Muslim's beliefs and practices of worship with traditions of foreigners from out of the scope of the Islam's teachings. It is also about the lack of science education which is further aggravated by the occupation of foreign nations who has created under-development of human resources of this country in many ways, including from its religiousity.

The impurity of Islam understood by most Indonesian Muslims at the beginning of dissemination constitutes to a form of adaptation through assimilation between Islam and local tradition that animism and dynamism are found, so that the Indonesian Muslims show things that are contrary with principles of Islam, especially those are related to the principles of Islamic's theology that rejects all forms of musyrik and khurafat. The sinkretisme happens and experiences over all archipelago in general and continues to be-so, at least before some Islamic reform movement is present as neutralizing the situation.

The entrance and development of Islam in the archipelago can be determined based on two sources which are external sources and internal sources from within the

${ }^{3}$ Koentjaraningrat, Pengatar Ilmu Antropologi (Cet. VI; Jakarta: Aksara Baru, 1986), h. 32. 
archipelago. There are four sources originating from outside the archipelago. First, the source was from Arabic. This opinion was expressed by Crawfurd, Keyzer, Nieman, De Hollander, Muhammad Naquib al Attas, Abdul Karim Amrullah (Hamka), and Abdullah Bin Nuh. They asserted that the Arabic traders had been doing trade activity with the nation tribes in the archipelago in the $7^{\text {th }}$ century $\mathrm{AD}$. In the $7^{\text {th }}$ century, the archipelago trading dominated by Sriwijaya Kingdom, particularly in the western part of the archipelago. ${ }^{4}$ Second, the source was from European. This source came from Marcopolo travel records. In 1292 AD, he stopped at the Royal SamuderaPasai. ${ }^{5}$ Third, the source was from Indian. This source pointed out that the Indian traders from Gujarat were nont only trading, but also actively spreading the religion and culture of Islam, especially to the people of the archipelago who lived in seashore. This theory was proposed by C. Snouch Hurgronye in 1883 AD, and was supported by Gonda, Van Ronkel, Marrison, R.A Kern, and C.A.O. Van Nieuwinhuize. ${ }^{6}$ Fourth, the resource was from China. This source was based on records that came after Ma Huan Ceng Ho. He noted that around 1400, there had been Muslim merchants who lived in the northern coast of Java. However, some sources from the Chinese else stated that in the $7^{\text {th }}$ century AD, an Arabic merchant became the leader in an Arabic Muslim's settlement on the coast of North Sumatra that was Ta Shih. ${ }^{7}$

\footnotetext{
${ }^{4}$ Busman Edyar dkk, (ed), Sejarah Peradaban Islam (Cet. I; Pustaka Asatrus: Jakarta, 2009), h. 207. Kerajaan Sriwijaya (Palembang), banyak meninggalkan bukti-bukti prasasti berangka tahun $775 \mathrm{M}$ dari semananjung Malaka sampai Kedah. Orang Arab menyebut Kerajaan Sriwijaya dengan sebutan Zabak, Zabay atau Sribuza.

${ }^{5}$ Dedi Supriyadi, Sejarah Peradaban Islam (Cet. I; Pustaka Setia: Bandung, 2008), h. 195. Kerajaan Samidera-Pasai adalah Kerajaan Islam yang dirintis oleh Malik al Shaleh/Meura Silo (659-688 H/1261-1289 M).

${ }^{6}$ Dedi Supriyadi, Sejarah Peradaban Islam...h. 191.

${ }^{7}$ Busman Edyar dkk, (ed), Sejarah Peradaban Islam...h. 191-192.
} 
Meanwhile, there were also sources of the archipelago, namely: First, the discovery of the tomb in Leran-Gresik. There was a name known as Fatimah Binti Maimun written on the tomb by year 1028 AD. Second, in the headstone tomb of Sultan Malik al-Salah, the ruler in the kingdom of Samudera Pasai, was found the data about Sultan's death time which was in the month of Ramadan in 676 AH / 1297 AD. Third, the tomb of Maulana Malik Ibrahim in Gresik, there was a note noticed "Died in 1419 AD" in which the sepulcher tomb brought from Gujarat. ${ }^{8}$

Some researchers of Islam history in South Sulawesi like Mattulada ${ }^{9}$, Abu Hamid ${ }^{10}$, Andi Zainal Abidin Farid ${ }^{11}$, Abdul Razak Daeng Patunru ${ }^{12}$, and Ahmad M. Sewang ${ }^{13}$ stated that the early seventeenth century Islam was made the official religion of the kingdoms that existed in this region. Islam became the official religion of the kings who massively followed by the people cannot be separated from the efforts of three scholars (Ulama), namely: Abdul Makmur Khatib Tunggal or ri Bandang

8. Badri Yatim, Sejarah Peradaban Islam (Cet. I; Raja Grafindo: Jakarta, 2007), h. 191-192.

9Mattulada, "Islam di Sulawesi-Selatan," dalam Taufiq Abdullah (ed.), Agama dan Perubahan Sosial (Cet. I; Jakarta: CV Rajawali, 1983), h. 222.

${ }^{10}$ Abu Hamid, Sistem Pendidikan Madrasah dan Pesantren di Sulawesi Selatan, dalam Taufik Abdullah (ed), Agama dan Perubahan Sosial (Cet. I; Jakarta: CV. Rajawali, 1983), h. 340.

${ }^{11}$ Andi Zainal Abidin Farid, "Lontara Sulawesi-selatan Sebagai Sumber Informasi Ilmiah", dalam Andi Rasdiyanah Amir (ed). Bugis Makassar dalam Peta Islamisasi; Selayang Pandang tentang Beberapa Aspek (Cet. I; Jakarta: IAIN Alauddin, 1982), h. 66.

12 Abdul Razak Daeng Patunru, Sejarah Bone....., h. 82.

13 Ahmad M. Sewang, Islamisasi Kerajaan Gowa (Abad XVI sampai Abad XVII) (Cet. II; Jakarta: Media Grafika, 2005), h. 91. 
Datuk, Abdul Jawad Khatib Bungsu or Datuk ri Tiro, and Datuk Sulaiman Khatib Eldest or Patimang ri. Those progenitors are considered as the most persons in the process of Islamisation in the field of religious, social, political, and cultural communities in South Sulawesi.

The name of Selayar (Tana Doang ${ }^{14}$ ) does not have any accurate information that is generally agreed to be determined where it is from and the meaning contains in it. There are many versions try to provide illumination to the riddle of Selayar's naming which is a very reasonable thing occurs when looking at the reality that there are still no certainty about the historical facts that can be used as the main base as authentic evidence of the origin of the Selayar's naming.

According to the sources, the name of Selayar is a name derived from the word Salayar, which means the screen. It is very related to the existence of indigenous Selayar type of boat that has one screen merely. The natives call Selayar with silajara or salajara which the prefix " $s i$ " presents meaning as "satu" (one). Similarly, the meaning of the word-gompo in local language means the stack or the heap in Indonesian. In a region which still allied with the island of Selayar such as Makassar calls it as silayara, and the Bugis calls silaja.

The notes that put the name of Selayar can be refered to mythology of Selayar called Sureq La Galigo. It is written that when a grand-daughter baby of Batara Guru in Bottinglangik (the up-world) comes to be born. The baby is not born, but his mother $W e$ 'Opu Sengeng has been nine days dying in pain.

\footnotetext{
${ }^{14}$ Merupakan sebutan lain bagi pulau Selayar, lebih kepada sebuah nama penghormatan. "Doang" dalam bahasa Indonesia ialah "doa". Pada pendapat lainnya mengartikan dan memaknai kata "doang" dalam bahasa lokal, merujuk pada bentuk pulau Selayar yang mirip dengan udang. Lihat juga dalam Tim Penyusun Kabupaten Kepulauan Selayar, Jelajah Pemerintahan dan Pembangunan Selayar-Tumanurung Akib Patta (Cet. I; t.p., 2004), h. 10-11. Lihat juga dalam Shaff Muhtamar, Buku Cerdas Sulawesi Selatan (Cet. I; Gowa: Yayasan Karaeng Pattingalloang Perpustakaan Abdul Rasyid Daeng Lurang, 2005), h. 27.
} 
Various vows have been made, including one of which is a war manipulated. In the game of these wars, Selayar people get involved, until the twins are born named by Sawerigading and $W e$ Tenriabeng. ${ }^{15}$

Other documents refered on to Selayar found in the book of Nagarakrtagama author by Mpu Prapanca. In the stanza 14, stanza 4 and 5 are written are the names of some of the areas in the eastern part of the archipelago, namely Bantayan (Bantaeng), Luwnk (Luwu '), Salaya (Selayar), Butun (Buton), Banggawi (Banggai), and Makassar. ${ }^{16}$ When analyzed, the areas which are written that are generally located on the coast. In the past, Selayar indeed a solid track trade traffic from east to west archipelago, into North Vietnam and South China, and vice versa. ${ }^{17}$

If seeing the oath archipelago declared by Patih Amangkubumi Gajah Mada in 1336, and then, the writing of Nagarakertagama can only be resolved by the Mpu Prapanca in 1365, that was one year after the death of Mahapatih Gajah

${ }^{15}$ R.A. Kern, I La Galigo (Cet. II; Yogyakarta: Gajah Mada University Press, 1993), h. 82.

${ }^{16}$ Mpu Prapanca, terj. I Ketut Riana, Nagara Krtagama (Cet. I; Jakarta: Kompas Penerbit Buku, 2009), h. 102.

\footnotetext{
${ }^{17}$ Dikaitkan dengan adanya penemuan keramik Sung dan Dehua (Yuan) yang berasal dari abad IX - XIV M. sejumlah situs bersejarah menunjukkan telah berlangsung hubungan antara Selayar dengan dunia luar melalui jalur laut sebelum diberitakannya nama Selayar dalam Nagara Kertagama oleh Mpu Tantular. Sebuah Laporan Penelitian Arkeologi oleh Muhaeminah dan Irfan Mahmud. 2006: h. 18.
} 
Mada in $1364^{18}$ that ordered the writing of it which meant the arrival of troops of Majapahit to Selayar certainly before the end of his year in 1359. It can be expected that the future conquest by Gajah Mada and fleet across the archipelago took place around the year 1337-1359.

Instead of the numbers of year written earlier, Nagarakertagama script also gave the number of years older that was during the reign of Kertanegara (1254-1292) who determined to make the country (Kingdom Singosari) as an archipelagic empire that had more power.. To achieve these objectives, it is necessary to integrate with other countries in the archipelago. At last, Kertanegara can enter Madura as part of Singosari Kingdom in 1280, then followed in 1284 Bali, Sumatra, and Kalimantan in 1286. Before having the Sunda to the west in 1290, Singosari naval forces successfully entered a cluster kingdom in the east which included Selayar and Bantaeng between the years 1287 to 1289, as a federation of kingdoms under Kertanegara Singosari. ${ }^{19}$

Based on the information from the Nagarakertagama, it can be estimated that the arrival of naval forces Singosari kingdom came for the first time in Selayar was around at the beginning / end of the year 1288. This information was also pointed out that with the entry of Selayar as a part of Singosari's power network, so it is included in the Selayar to join macro-economic political horizon in the archipelago, which indirectly affects the role in the next period in the sphere of commerce and islands of the archipelago.

${ }^{18}$ Slamet Muljana, Runtuhnya Kerajaan Hindu-Jawa dan Timbulnya Negara-Negara Islam di Nusantara (Cet. I; Jogjakarta: LKis, 2015), h. xiii.

19 A. Irfan Mahmud, dkk, Bantaeng Masa Prasejarah ke Masa Islam (Cet. I; Makassar: Masagena Press, 2007), h. 123. 
The additional information also contained information about the Selayar that there a description in the XV century when the king of Gowa Daeng Selayar Matanre put Selayar into his territory, in addition to Garassi, Katingan, Parigi, Lunch and Sudiang. ${ }^{20}$ That situation did not last long, as in the reign of the king of Gowa-X, I Manrigau Daeng Bonto Karaeng Lakiung Tunipallangga Ulaweng (1546-1565), Selayar had entered into the territory of the Sultanate of Ternate. In Manggorai's government, Daeng Mameta Karaeng Bontolangkasa Tunijallo (1565-1590), precisely in 1580, Selayar became part of the kingdom of Gowa after the treaty of friendship between the Kingdom of Gowa and the Sultanate of Ternate, which agreed handed over Selayar tenure from the Sultanate of Ternate to the part of the Gowa Kingdom.

\section{Research methods}

This research is to re-examine the history of events that happened in the past by using accurate data and historical facts. There are four steps that must be considered in conducting historical research which are Heuristics, Source Criticism, Interpretation, and Historiography. ${ }^{21}$ (1) Heuristics is a process of gathering all historical sources related to the object of research to be conducted. All kinds of writings or researches put the sources of history as a necessary condition that must be provided. Without any resources of history, the story about the past cannot be reconstructed by historians. (2) Source Criticism is the next stage which is carried out to determine the authenticity and credibility of the source of history. Determining the authenticity of a resource associated with the source materials

${ }^{20}$ Abdul Razak Daeng Patunru, Sejarah Gowa (Makassar: Yayasan Kebudayaan Sulawesi Selatan Tenggara, 1967), h. 19.

${ }^{21}$ Sartono Kartodirjo, Pendekatan Ilmu Sosial dalam Metodologi Ilmu Sejarah (Cet. I; Jakarta: Gramedia, 1992), h. 4. 
used is called external criticism, while the selection of information contained in historical sources whether can be trusted or not, is called internal criticism. (3) Interpretation is an emerge synthesis based on the subject of the study. The main theme of the study is a rule which is used as a criterion in combining historical data. At this stage, it is urged to have accurate and objective attitude historians, mainly the subjective interpretation of the historical facts, (4) Historiography is various statements about the past which has been written subsequently synthesized in the form of historical narrative. At this point, historians will carry out what is said G.J. Rinier as a serialization in the historical story. ${ }^{22}$ Therefore, this study uses historical method descriptive analysis, which describes, explains, and gets accros the facts of history. The research in this thesis is qualitative that is library research and field research as the category. ${ }^{23}$

Library Research is a way to obtain data or information through the library by reading literatures, books, magazines, or other scholarly works, as well as a variety of articles that has to do with the discussion in this study. Some literatures will greatly assist researchers in obtaining additional information, so thatit can obtain conformity data from field research. The accuracy, then, of the data that is found to be more valid.

Field Research is a method or technique to obtain data or information in the field which is object of research. In this research, the researchers use several methods as following: (1) The historical method / documentation is one of the main methods used to collect data by means of records from the

\footnotetext{
${ }^{22}$ Abd. Rahman Hamid dan Muhammad Saleh Madjid, Pengantar Ilmu Sejarah (Cet. I; Yogyakarta: Ombak, 2011), h. 43-51.
}

${ }^{23}$ H. Kaelan, Metode Penelitian Agama, Kualitatif Interdisipliner (Cet. I; Yogyakarta: Paramadina, 2010), h. 177. 
archives that are directly related to the document of Selayar Muhammadiyah which is still kept or some privacy documents owned by the figures. (2) The interview is a method of data collection by the way of question and answer in turn. In the implementation of this interview, the researchers will conduct a discussion with the witness of history and some influential figures who know a lot about the development of Muhammadiyah in Selayar. It is intended for the researchers to be able to identify and re-elaborate the development process of Muhammadiyah in Selayar from deep and special information that is deep and special, to the general one.

\section{The Yore of Islam in Selayar}

In the years before the Islamic reform movement, public's faith of Selayar is majority Muslim. Regarding to the arrival and development of Islam in Selayar, the researchers found that there are at least three different views in the past and actors deployment as well as in the aspect of teaching.

At first, the King of Selayar had closed relationship and special role in the control of the Sultanate of Buton. This was evident by important information from around 1491 that was a king of Selayar named Opu Manjawari (According to one source, Opu Manjawari came from the island Kalao, Selayar ${ }^{24}$ or La Manjawari together with Laki Laponto (a son of Sugimanuru, king Muna all III) helped the La Mulae (Raja Buton V), fighting and defeating the fleet sultanates of Ternate led by La Bolontio which at that time controlled waters Banda, Selayar, until Moro island (Philippines). The relation also continued between the king Manjawari with the king-VI Buton that was finally in 1528 became the first sultanate under the power Laki Laponto (Sultan Muhammad Yisa Qaimuddin / Murhum) increasingly intertwined when Opu Manjawari appointed as the Sapati. The coming event was no less

${ }^{24}$ Muchtar Adam, Sejarah Selayar; Rakyar Bersatu Mengusir Penjajah (Cet. I; Bandung: Makrifat Media Utama, 2015), h. 21. 
important that there was the first Sultan marriage with a daughter of Selayar who later gave birth to a boy named La Tumparasi Qaimuddin title of Sultan, Sultan Buton II. ${ }^{25}$

There was a cooperation in the military, and continued by giving office from Raja Buton to Opu Manjawari as Sapati reinforced the indications that the contiguity of Selayar society and Islam in the Sultanate of Buton had a huge opportunity, condemed Opu Manjawari certainly had a great power in Selayar. The situation was also strengthened by the marriage of Sultan Muhammad Yisa Qaimuddin / Murhum with a daughter of Selayar showed indications that the daughter was married to the Sultan, of course, already converted to Islam. One thing that was important to know, that up to the present time there are still many Shia's influence to work on the problems in Selayar society's worship. The condition lasted unconsciously by most traditional Selayar society in general which was also very identical and closely associated with the terrific understanding of Shia found in the sultanate of Buton.

Second, there was is a strong resource pointed out that Islam was growing in Selayar came from Ternate, brought by Sultan Babullah along with the kingdom of religious leaders. On one occasion came by in Selayar after his official visit to the kingdom of Gowa, noted in 1580, the Sultan of Ternate Babullah royal visited to the capital of kingdom of Gowa, Somba Opu. During the visit, an agreement had been successfully agreed that a political agreement between the two kingdoms. Sultan Babullah handed over Selayar island to the kingdom of Gowa, Manggorai Daeng Mammeta Karaeng Bontolangkasa Tonijallo, which previously was under vassal

${ }^{25}$ Lihat dalam Buku Pengawasan, Monitoring, Evaluasi, dan Pelaporan Pelaksanaan Program Pengelolaan Kekayaan Budaya, Dinas Kebudayaan dan Pariwisata Kota Baubau, 2013, h. 3-9. 
kingdom of Ternate. ${ }^{26}$ On the way back to Ternate, Sultan stopped in a few places on the south coast of South Sulawesi, like Selayar and Southeast Sulawesi. On this trip, the Sultan took the opportunity to spread the religion of Islam. ${ }^{27}$

Third, this argument was a strong thought embraced by the people of Selayar in general. That thought stated that the arrival of Islam in Selayar was by a special role of Dato Di Tiro marked by the construction of the first mosque in Gantarang, the east coast of Selayar. Territory town-ship which was located about $12 \mathrm{~km}$ from Benteng downtown. As embodied in historical writing that, the spread of Islam in South-Sulawesi performed by three great scholars as famous as muballigh, namely:

1. Abdul Makmur, Sole Khatib Dato 'worship, which later became known as the title of Dato' Ribandang, spreading Islam in Gowa and surrounding areas by using the teachings of Islamic law as its teachings.

2. Eldest Sulaiman Khatib, later better known by the title of Dato 'Patimang, first along Khatib Abdul Makmur Tunggal in Gowa, then came back and stayed in Luwu' and spreaded the teachings of Islam by prioritizing Tauhid, using the old belief (Sure ' I La Galigo) as a way of approach.

${ }^{26}$ Lihat dalam Disertasi Mardiadi Armin; Tarekat Muhdi Akbar dalam Kehidupan Keberagaman di Kabupaten Selayar-Perbedaan dalam Tinjauan Etika, menuliskan bahwa hubungan populasi Ternate, Halmahera dengan Selayar dapat ditemukan dalam keterangan Gilbert Hamonic: Ainsi encore 1837 les ilots proches de Galela et Tobelo (sur Halmahera) e tant de veritable "neds de corsais" peuples de "refugies et bannis Celebes, Cream et autre iles". Les Hollandais transporterent quatre cents de ces "pirates" a Selayar et leur donnerent des terres a colonizer, dalam Le Langage des Dieux (Paris: Editions du CNRS, 1987), h. 4 .

${ }^{27}$ Ahmad M. Sewang, Islamisasi Kerajaan Gowa Abad XVI-XVII (Cet. I; Jakarta: Yayasan Obor Indonesia, 2005), h. 76. 
3. Youngest Khatib Abdul Jawad, a stop and dwell in the Tiro (Bulukumba), so that later became known by the title of Dato 'ri Tiro. He developed the teachings of Islam with Sufism approach to the surrounding area.

Tiro area in Bulukumba was an area that was directly adjacent to Selayar Island which was only separated by a strait stretch of Selayar, so that the third view of the spread of Islam in Selayar Island was strong also to be accepted. When compared with the two previous opinions, the third opinion was more recent era of the two previous opinions, which took place at the beginning of the XVI century.

An important note can be associated with those opinions is that there are similarities mengang tradition in $\mathrm{Aceh}^{28}$, which is held by eating meat together with family and relatives the day before Ramadhan. The tradition is the same thing done by local traditions of Selayar society survived until today, the tradition in the language of Selayar called ma'gang or amma'gang. If observed in terms of the language is also found out that there is an adoption vocabulary of mengang in Aceh becomes ma'gang or amma'gang in Selayar. This information is quite relevant to previous information, which is Dato Tiro comes from the Minangkabau does have historical relation with the Aceh region $^{29}$, besides these areas are indeed part of the island of Sumatra.

In the span of sufficient time till the arrival of Mubammadiyah and other reformist movement, Selayar society is broadly embraced Islam. They are fanatical followers of Islam, but in practice still take place deviants from the true teachings of Islam. This is evident in religious practices such as prayer

${ }^{28}$ Net Tv, Morning Show-Muslim Corner; Tradisi Meugang Aceh, Senin, 6 Juni 2016 ditayangkan tepat pada Pukul 07:47.

${ }^{29}$ Hasanuddin, dkk, Spektrum Sejarah Budaya dan Tradisi Bulukumba (Cet. II; Makassar, Hasanuddin University Press, 2012), h. 43. 
and fasting, for example, even though sometimes do not execute the two commands are required, they still are not willing to call as a non-Muslim and all activities of the ceremonies in the community such as weddings, circumcisions, and so on, remain to be implemented in rules that are prescribed religion of Islam.

Selayar society in general at the time before the arrival of the idea of a reformer by $\mathrm{H}$. Hayyung and Muhammadiyah, still cannot separate between religious ceremonies and customs in a royal tradition that consistently to be implemented continuesly. Faith and worship have mingled with superstition (tahayul), heresy (bid'ah), and khurafat.

The concrete examples in a distorted belief as following: (1) To believe in the dignity of human glory be seen and measured by race, ethnicity and descent, (2) To adore gaukang (kingdom), saukang (idols) objects considered sacred and has magical powers and are believed to bring good and bad things in life, (3) a talisman (azimat) intended as a repellent reinforcements, (4) To trust their good days and bad, or bad luck, (5) beliefs about the footprints Prophet Muhammad in Gantarang, Selayar, (6) To trust in the pakkojokang, namely a hole in Gantarang, Selayar which is believed, that when the Islamic ummah has completed the pilgrimage in Mecca, and then do not visit pakkojokang, then their performence from Mecca is considered invalid or void. Conversely, for those who are not able to perform the Hajj, it is enough with the Eid al-Adha prayers for seven consecutive times in Gantarang, then the person has been assessed as Hajj. Pakkojokang is dedicated also for someone who wishes to determine his or her livelihood. ${ }^{30}$ Most of religious practices mentioned before is the part of the Makka Keke's belief system that have been embraced by the villagers Gantarang in Selayar Island.

\footnotetext{
${ }^{30}$ Skripsi Muhammad Yasir yang berjudul KH. Hayyung: Tokoh Pembaharu Masyarakat Islam di Selayar 1918-1961. Diselesaikan dalam rangka penyelesaian studi di Universitas Hasanuddin, Fakultas Sastra pada tahun 1994, h. 14-15.
} 
Muh. Nur Baso also provides an illustration of the public Selayar's faith that everything is always associated with the tradition and belief. The forms of these beliefs in everyday life, for example, if there is a child to be circumcised, then it are sought for an elder who is considered sacred. It is done for a child when he/she grows up to marry someone who has a higher degree of it or will allow him to not marry someone of lower degree than himself. For a child who has not healed is banned to overstep certain objects because it is believed will lead to the child becomes impotent. ${ }^{31}$

Some of these depictions have indeed demonstrated that the teachings of Islam embraced by the community and run by Selayar society in the period before the arrival of various reform movement have been away from the source of the teachings of Islam, namely the Qur'an and Hadisth. It is indeed possible when public knowledge about Islam in the past is still very shallow, so that the risk of acculturation between religion and ancestral beliefs are first believed to be difficult to avoid. The limitation of their understanding of the teachings of Islam shows a dakedensi in the dimension of Islam that they believe, as a result of the acculturation and senkretisme. This incident becomes a major trigger for the birth of a wide range of belief systems in society in which professes Islam but in practice still entangled into the symbols of the old belief. The same applies in the Belief System of makka Keke located in the village of Bata Lalang Gantarang Selayar Islands.

${ }^{31}$ Muh. Nur Baso, Kebudayaan Daerah Selayar dan Hubungannya dengan Kebudayaan Daerah Lainnya, Makalah, (Kantor Departemen Pendidikan dan Kebudayaan Kabupaten Selayar, 1982), hal. 21. 


\section{The Belief System of Makka Keke and Its Existence}

Gantarang is one of the great kingdoms on the island of Selayar. Citizens who inhabit this village as a whole are Muslim and adhere to Makka Keke's belief system. Their knowledge of Islam is that not much different from the knowledge and experience of religion for Muslims in general. The difference is because they add elements of religious practice that does not exist in Islam.

Makeka Keke means semi Mecca. ${ }^{32}$ None of the people in the village Gantarang knows when and where the birth of the belief system. They simply believe that Makea Keke is the name given by the Prophet Muhammad when stopping in Gantarang village on the way to determine where the center of the earth is. The Prophet Muhammad's trip starts from the east (Masyrik) which when until midday prayer, then it is determined as the center of the earth. They believe that the only place I have ever visited by the Prophet Muhammad in a safari before arriving at Mecca just Gantarang Lalang Bata (full name of the village according to the locals). They concluded that, if at the time of the Prophet Muhammad layover in Gantarang and have entered the Zohar prayer time, then Gantarang Lalang Batalah will be the center of the earth and not in Mecca.

Gantarang Lalang Bata becomes Makeka Keke since the ancestors of Gantarang, and not in the era of kings like Pangali Patta Raja accepted Islam. Gantarang becomes Makka keke since Prophet Muhammad set foot on the ground Gantarang Lalang Bata in accordance with their belief that the incident occurred

\footnotetext{
${ }^{32}$ Wawancara dengan Muhammad Asrul D.M. Mantan Kepala Dusun Gantarang Lalang Bata. Dilaksanakan pada hari Jum'at, 5 Agustus 2016, pada Pkl. 15:00 Wita.
} 
after Isra 'and Mi'raj. ${ }^{33}$ After Pangali Patta Raja (King Gantarang around the 16th century) embraced Islam and proclaimed Islam as the religion of the kingdom Gantarang, then Gantarang is not only the capital of the kingdom, but also becomes central to the spread of Islam throughout the islands Selayar along with the influence of the belief system Makka Keke espoused.

Having apart from that understanding, Gantarang kingdom which can, then, be controlled by the Dutch colonial government taking advantage of the kingdom to strengthen its influence. The beliefs that hereditary are, then, further exaggerated in order to obscure the purity understandings of Islam in society that is considered to be a serious threat. The sanctity of the place was created as a sanctuary and shall be visited by residents of the Selayar Island. Since then, Gantarang passing Bata along Makka's Belief System Keke started influencing and existence as a place of Hajj besides to the holy land of Mecca and all religious practices that deviate from the purity of Islam.

The two opinions above shows continuously. The first opinion that stated that belief system of Makka Keke is an emik of society Gantarang Lalang Bata centuries long time ago that is believed to favor a second opinion that said it was used by the Dutch colonial government to ensure influence and disrupt the joints of Islam that would be able to pose a threat. Most likely these conditions also are intended to support the mission of Christianizing the objectives of another Dutch colony on colonies in the archipelago.

Adherents of Makka Keke's belief system assume that the worship experience is not quite done with the Shari'a only, but it can be also a perfect behavior overall (Shari'a, tarikat, hakikat and Makrifat) that cannot be separated from one

${ }^{33}$ Patta Lolo, D.M., Makka Keke di Gantarang Kabupaten selayar Ditinjau dari Segi Aqidah Islam. Risalah Ilmiah (Skripsi, Ujung Pandang: IAIN), h. 47. 
another. It is associated with the incidence of human beings who come from the four elements, namely; waddu, waddi, semen, and manikang. Waddu means humans come from the land which is the incidence of the human body. Waddi means humans come from the water that is the heart of events. Manni means people from a fire which is the incidence of human lives. Manikang means humans come from the wind which is the occurrence of a secret. The four elements are believed to bring remembrance and in manikang is an emerge of the four elements in which man is made, as well as a man devoted servant to his Lord stemming from these elements. ${ }^{34}$

The adherents of Makka Keke' belief systems continue to implement the teachings of Islam, but in Shari'a and hakikat practice. It can be known from their understanding of "Patapaentenga agama islanga nampa nakana religious pappokokinna islanga Antu tallui, uru-uruna satinja, makaruana Sahada', makatalluna junnu" which mean "Upheld the Islamic religion, the basic elements of Islam that there are three cases, namely istinjaa, Syahadat and Junub. Theses inheritances are believed to be hereditary by adherents of Makka Keke's belief systems until now.

Istinjaa in the native language in Selayar's dialeg called the Satinja. Adherents of Makka Keke's belief systems always be careful in life, especially related to the religion of Islam. This can be seen when they eat. Before eating them first purify themselves, are intrinsically holy by washing the mouth include the lips, under the tongue, palate, throat bone, all of which are accompanied by the intention Alifu ( $\mathrm{a}, \mathrm{i}$ and $\mathrm{u}$ ). These sounds are what is intended when rinsing. The same thing has been

${ }^{34}$ Wawancara dengan Sikina, salah seorang tetua adat di dusun Gantarang lalang Bata. Dilaksanakan pada hari Jum'at, 5 Agustus 2016. Pada Pkl. 16:30. 
done to other activities with different ritual movements, such as toileting; purify themselves from hunger, and others. ${ }^{35}$

Shahada, if a person wants to do wudlu, the water to perform ablutions is water which must be mixed with water alqautsar (which, according to adherents of this belief system is the water that comes from the palate and taken with the thumb. The thumb is used then dipped in water to be used for the last wudlu accompanied by reading Arabic mixed with local languages for every movement. ${ }^{36}$

Regarding to a prayer, adherents of Makka Keke's belief systems believe that there are 13 pillars of prayer, the human resources and come from three properties. Properties derived from the nature of God, namely: lives, hearing, sight, smell, and feeling. A property derived from nature's father is; bones, tendons, hair, and nails. Properties derived from mother nature, namely; brains, flesh, skin and blood. Furthermore, when viewed in the procedures of prayer also vary significantly from the customs of Muslims worship. Some special ritual they do is; (1) before praying, they first greeted the guard time with greeting Arabic mixed with the local language, (2) before standing to perform takbir, to hold firstly a place of prostration while hold the breath with a particular reading, then hold your thumb right signaled as beach-head point that should not be moved and continued with several other rituals before takbir.

${ }^{35}$ Tesis Sirajuddin Ismail, Sistem Kepercayaan Makka Keke di Gantarang Selayar, h. 53-57.

${ }^{36}$ Wawancara dengan Sikina, salah seorang tetua adat di dusun Gantarang lalang Bata. Dilaksanakan pada hari Jum'at, 5 Agustus 2016. Pada Pkl. $16: 30$. 
Broadly speaking, the salat from the greeting as the final prayer has many differences with prayers of Muslims in general. ${ }^{37}$

There are two kinds of Junubs for this beliver that are junub Bakkaand a state of impurity ki'di' (small junub). In order to purify themselves from junub is just the same as what the Muslims in general do, as shari'a's compliant. Things are different to purify of small junub with a special ritual practices such as a drop of water is placed over the head, accompanied by a speech in the heart of $a, i$ and $u$, "a" very nature of the Creed, "i" istinjaa, and "u" junub.

Instead of mentioning before, a wide variety of other religious rituals for adherents of Makka Keke's belief systems has elements of both ritual and reading practice that distinguishes its adherents to Islam purely in accordance with the guidance of the Qur'an and hadisth. They believe in holy places like possi'na Gantarang which is a place that ever visited by the Prophet Muhammad. The place is a hole called pakkojokang (inserting a hand into the hole) which has special significance in the rituals. Someone who does pakkojokan believed to determine his fate in the future. There are also foot-prints that are believed to be the foot-prints of the Prophet Muhammad who came by in Gantarang Lalang Bata. They believe that the foot-prints are only visible to people who are lucky and blessed by Allah. Some other places are also purified has a history, role and special functions for those who visit it. It goes against the teachings of Islam are still being carried out today, including what is the most surprising that there is no unauthorized person from Hajj before visiting the place. Regarding to Hajj, they also

${ }^{37}$ Wawancara dengan Muhammad Asrul D.M. Mantan Kepala Dusun Gantarang Lalang Bata. Dilaksanakan pada hari Jum'at, 5 Agustus 2016, pada Pkl. 15:00 Wita.

\footnotetext{
${ }^{38}$ Wawancara dengan Sikina, salah seorang tetua adat di dusun Gantarang lalang Bata. Dilaksanakan pada hari Jum'at, 5 Agustus 2016. Pada Pkl. $16: 30$.
} 
believe that people were born in the village of Bata Lalang Gantarang should not be Hajj because if they insist to do so, they will never come back to the region. It is associated with the belief that they adore the sanctity and the role of the weeds Gantarang Bata as sanctuaries ever visited by the Prophet Muhammad.

\section{The Implication of Research}

The folklore about belief system of Makka Keke started since the Prophet Muhammad stopped to do Sunnat prayer from masyrik to Maghrib in order to determine where the center of the earth is. Adherents of Belief Systems Makka Keke have an understanding and religious practices blend between old faiths them with pure Islamic teachings. Adherents of this belief do concede that make the Hajj to Mecca is the fifth pillar of Islam and every Muslim is obliged to run it if he/she can, but it must be coupled with visits or Hajj to Gantarang Lalang Bata along with some places are holied. Those people who are born in Gantarang shall not perform Hajj because if the do, they will never return to its original place.

The adherents of Makka Keke's belief systems believes that Gantarang Lalang Bata has a quality and distinctive compared to other areas in the Selayar island. They always continue hereditary to believe that the spirit of the Prophet is in place and differiantiate over other regions. The privilege which they believe sometimes is to be one of special pride for descendants of the original Gantarang Lalang Bata.

The belief that they profess is no more an understanding of the transition. As the beginning of symbols of Islam in Selayar, with the capacity and the history of the existence of Islam in Gantarang Lalang Bata, the place is so respected. It looks like this place formerly was used as the main place in various religious rituals around the area of Selayar. As one example is the implementation of the Hajj rituals, some of the findings in the form of heritage that is synonymous with various forms of objects as miniature Mecca became evident 
that this place was long ago used as proper training of Hajj. But the understanding of it turned into a perversion of Islam over time. All kinds of things they consider to have had mystical powers and supported by folklore hereditary entrenched from one generation to the next generation.

These deviations must be serious and will be very difficult to remove. Until now, the adherents of this belief system still continue to believe and carry out a wide range of different religious practices by followers of Islam in general. The settlement of the location where the adherents are found is very strategic. Although there is no prohibition for anyone who wants to visit and impressed open for people, but they are not easily influenced by the nature of the outside of their beliefs. Things look up to now, although it has been through the ages with various forms, they still continue to maintain and take a good care of belief systems fo Makka Keke that they inherited from their predecessors.

\section{Bibliography:}

Abdul Razak Daeng Patunru, Sejarah Gowa (Makassar: Yayasan Kebudayaan Sulawesi Selatan Tenggara, 1967.

Adam, Muchtar. Sejarah Selayar; Rakyar Bersatu Mengusir Penjajah. Bandung: Makrifat Media Utama, 2015.

Armstrong, Karen. A History of God: The 4,000-Year Quest of Judaism, Christianity and Islam, terj. Zaimul Am, Sejarah Tuhan: Kisah 4.000 Tabun Pencarian Tuban dalam AgamaAgama Manusia. Bandung: Mizan Pustaka, 2012.

Edyar, Busman, dkk. (ed), Sejarah Peradaban Islam. Pustaka Asatrus: Jakarta, 2009

Hamid, Abu. Sistem Pendidikan Madrasah dan Pesantren di Sulawesi Selatan, dalam Taufik Abdullah (ed), Agama dan Perubahan Sosial. Jakarta: CV. Rajawali, 1983.

Hamid, Abd. Rahman, Muhammad Saleh Madjid. Pengantar Ilmu Sejarah. Yogyakarta: Ombak, 2011. 
Hasanuddin, dkk. Spektrum Sejarah Budaya dan Tradisi Bulukumba. Makassar: Hasanuddin University Press, 2012.

Kaelan, H. Metode Penelitian Agama, Kualitatif Interdisipliner. Yogyakarta: Paramadina, 2010.

Kartodirjo, Sartono. Pendekatan Ilmu Sosial dalam Metodologi Ilmu Sejarah. Jakarta: Gramedia, 1992.

Kern, R.A. I La Galigo. Yogyakarta: Gajah Mada University Press, 1993.

Koentjaraningrat. Kebudayaan, Mentalitas dan Pembangunan. Jakarta: PT. Gramedia Pustaka Utama, 2015.

Koentjaraningrat, Pengatar Ilmu Antropologi. Jakarta: Aksara Baru, 1986.

Lolo D.M., Patta. Makka Keke di Gantarang Kabupaten selayar Ditinjau dari Segi Aqidah Islam. Risalah Ilmiah. Skripsi, Ujung Pandang: IAIN.

M. Sewang, Ahmad. Islamisasi Kerajaan Gowa (Abad XVI sampai Abad XVII). Jakarta: Media Grafika, 2005.

Mahmud, A. Irfan, dkk. Bantaeng Masa Prasejarah ke Masa Islam. Makassar: Masagena Press, 2007.

Mattulada,. "Islam di Sulawesi-Selatan,"..dalam .Taufiq Abdullah (ed.), Agama dan Perubahan Sosial. Jakarta: CV Rajawali, 1983.

Muhtamar, Shaff. Buku Cerdas Sulawesi Selatan. Gowa: Yayasan Karaeng Pattingalloang Perpustakaan Abdul Rasyid Daeng Lurang, 2005.

Muljana, Slamet. Runtubnya Kerajaan Hindu-Jawa dan Timbulnya Negara-Negara Islam di Nusantara. Jogjakarta: LKis, 2015.

Nur Baso, Muh. Kebudayaan Daerah Selayar dan Hubungannya dengan Kebudayaan Daerah Lainnya, Makalah. Kantor Departemen Pendidikan dan Kebudayaan Kabupaten Selayar: 1982. 
Riana, I Ketut. Nagara Krtagama. Jakarta: Kompas Penerbit Buku, 2009.

Supriyadi, Dedi. Sejarah Peradaban Islam. Pustaka Setia: Bandung, 2008.

Tim Penyusun Kabupaten Kepulauan Selayar. Jelajah Pemerintahan dan Pembangunan Selayar-Tumanurung Akib Patta. t.p., 2004.

Yasir, Muhammad. KH. Hayyung: Tokoh Pembaharu Masyarakat Islam di Selayar 1918-1961. Skripsi IAIN Ujung Pandang: 1994.

Yatim, Badri. Sejarah Peradaban Islam. Raja Grafindo: Jakarta, 2007.

Zainal, Andi Abidin Farid. "Lontara Sulawesi-selatan Sebagai Sumber Informasi Ilmiah", dalam Andi Rasdiyanah Amir (ed). Bugis Makassar dalam Peta Islamisasi; Selayang Pandang tentang Beberapa Aspek (Cet. I; Jakarta: IAIN Alauddin, 1982. 